Свидрук I. I.,

irena_svidruk@ukr.net, ORCID ID:0000-0002-3099-6449,

Researcher ID: F-8502-2019

д.е.н., проф., професор кафедри менеджменту, Львівський торговельно-економічний університет, м. Львів

Клепанчук О. Ю., o.klepanchuk@gmail.com,ORCID ID: 0000-0001-7764-614X

к.е.н., дои., доцент кафедри фінансового менеджменту, Львівський національний університет імені Івана Франка, м. Львів

\title{
СИСТЕМНИЙ АНАЛІЗ РОЗВИТКУ СПОЖИВЧОГО РИНКУ УКРАЇНИ
}

Анотація. Статтю присвячено багатофакторному аналізу особливостей розвитку споживчого ринку України як відкритої системи, в якій одночасно задовольняються антагоністичні иілі товаровиробників і торгових посередників щзоо зростання прибутковості і капіталізації та споживачів щзодо мінімізації затрат на задоволення попиту. Споживчий ринок досліджували в якості інструменту забезпечення соціально-економічноі стабільності. Здійснено структурно-динамічний аналіз розвитку споживчого ринку у 2014-2020 рр. та виявлено його стабільне зростання попри незначне зниження обсягу реалізації послуг. Проаналізовано зміни товарної структури споживчого ринку. Виявлено, щуо найбільша частка витрат домогосподарств була сконцентрована на ринку продовольчих товарів, де спостерігалося стрімке зростання споживчих иін. Показано, щчо в цілому середньомісячні сукупні витрати домогосподарств на споживчому ринку скоротились, особливо на непродовольчі товари $і$ послуги, щчо спричинено сочіально-економічною невпевненістю споживачів. Виявлено, щчо знецінення гривні, скорочення поточних видатків бюджету та стрімке підвищення тарифів на житловокомунальні послуги призвели до зменшення рівня доходів населення і підвищення рівня бідності. На подолання проблеми спрямоване приєднання України до програми ООН “Цілі Сталого Розвитку 2016-2030”. Здійснено факторний аналіз впливу розвитку ринків непродовольчих товарів та послуг на зростання ВВП Украӥни. Виявлено, щуо стан споживчого ринку продовольчих товарів практично не впливає на динаміку номінального ВВП, тоді як зростання ринків непродовольчих товарів та послуг гарантовано призводить до збільшення ВВП. Подальші дослідження запропоновано скерувати на розробку інституційного інструментарію концептуальних перетворень внутрішнього споживчого ринку.

Ключові слова: продовольчі і непродовольчі товари, споживчі послуги, домогосподарства, інституційне регулювання, споживчі ціни.

Svydruk I. I.,

irena_svidruk@ukr.net, ORCID ID:0000-0002-3099-6449,

Researcher ID: F-8502-2019,

Doctor of Economics, Professor, Professor of the Department of Management, Lviv University of Trade and Economics, Lviv

Klepanchuk O. Yu., o.klepanchuk@gmail.com, ORCID ID: 0000-0001-7764-614X,

Ph.D., Associate Professor, Associate Professor of the Department of Accounting and Taxation, Ivan Franko National University of Lviv, Lviv

\section{SYSTEM ANALYSIS OF UKRAINE'S CONSUMER MARKET DEVELOPMENT}

\footnotetext{
Abstract. The article is devoted to the multifactor analysis of the peculiarities of the consumer market of Ukraine as an open system, which simultaneously meets the antagonistic goals of producers and trade intermediaries to increase profitability and capitalization as well as consumers to minimize the cost of meeting demand. The consumer market was studied as a tool to ensure socio-economic stability. A structural and dynamic analysis of the development of the Ukrainian consumer market in 2014-2020 was carried out and its stable growth was revealed despite a slight decrease in the services volume of sales. Changes in the commodity structure of the consumer market are analyzed. It was found that the largest share of household expenditures was concentrated in the food market, where there was a sharp rise of consumer prices. It is shown that in general the average monthly total expenditures of households in the consumer
} 
market decreased, especially for non-food goods and services, which is caused by socio-economic uncertainty of consumers. It was found that the devaluation of the hryvnia, the reduction of current budget expenditures and the rapid increase in tariffs for housing and communal services have led to household incomes decrease and poverty increase. Ukraine's accession to the UN Sustainable Development Goals 2016-2030 Program was aimed at overcoming the problem. A factor analysis of the impact of the non-food goods and services markets development on Ukraine's GDP growth was performed. It was found that the state of the consumer market of food products has almost no effect on the dynamics of nominal GDP, while the growth of markets for non-food goods and services is guaranteed to lead to an increase in GDP. Further research is proposed to focus on the development of institutional tools for conceptual transformations of the domestic consumer market.

Key words: food and non-food goods, consumer services, households, institutional regulation, consumer prices.

JEL Classification: D51; E21; L16; L17

DOI: https://doi.org/10.36477/2522-1205-2021-64-12

Постановка проблеми. Передумовами високоінтенсивного розвитку внутрішнього споживчого ринку $\epsilon$ сприятливе, інституційно регульоване бізнес-середовище, розвиток комунікацій, інфраструктурне оновлення економічної системи, що дозволяє знижувати бар'єри входу на ринок та позитивно позначається на ефективності ринкової взаємодії. Споживчий ринок традиційно розглядають в якості інструменту забезпечення соціальноекономічної стабільності в суспільстві, акцентуючи дослідження на аспектах його цінової збалансованості та ефективності товаропотоків. Дисонансні умови суспільного розвитку консолідують різноспрямовані вектори ринкової взаємодії, виступають драйвером конструктивної кооперації ринкових суб'єктів, посилюють роль динамічності господарських суб'єктів та їх інтегративність у взаємодії 3 державними інституціями. Постіндустріальна конкурентна ситуація, що характеризується динамізмом, багатоаспектністю інтересів та агресивністю у досягненні цілей ринкових суб'єктів, актуалізує необхідність врахування впливу всієї сукупності факторів конкурентного середовища розвитку та ефективності функціонування споживчого ринку. Отож, постає необхідність багатофакторного аналізу особливостей розвитку споживчого ринку України як відкритої системи, в якій одночасно задовольняються антагоністичні цілі товаровиробників і торгових посередників щодо зростання прибутковості і капіталізації та споживачів щодо мінімізації затрат на задоволення власного попиту.

Аналіз останніх досліджень і публікацій. Різні аспекти розвитку споживчого ринку завжди знаходилися в центрі уваги науковців. Слід відзначити дослідження ринків Н. Попадинця, в якому описано систему завдань, функцій і методологічних принципів його розвитку [7]. Аналіз тенденцій розвитку споживчого ринку, здійснений Ю. Уманцівим та М. Катраном, дозволив виявити причини появи недосконалої цінової конкуренції та негативних змін у структурі сукупної пропозиції [9]. Цікавою є аргументація Т. Яхно про взаємозалежність змін матеріальних умов домогосподарств та якісних змін споживчого ринку [13]. Серед вагомих проблем розвитку споживчого ринку Н. Федоронько та Н. Ковальчук виокремлюють недосконалість нормативної бази та низьку мотиваційну основу, що провокує міграційні процеси [10]. В. Шликова та О. Леванда також наголошують на проблемах зростання імпортозалежності споживчого ринку і підкреслюють необхідність створення інституційних передумов його розвитку [12].

К. Колеснікова та Т. Руденко вивчали можливість напрацювання інструментів подолання кризових явищ у ринковому середовищі, зокрема розглядали ефективність економічного та адміністративного стимулювання ринкової активності [4]. М. Чорна та співавтори запропонували підхід до оцінювання можливостей трансформації ринку, запропонувавши модель створення нових ринкових просторів [11]. Значну інформацію для подальших наукових пошуків надає дослідження В. Громова, який рекомендував інституційно регулювати споживчий попит через соціальну політику [1]. Ми цілком поділяємо позицію Т. Данилюка про нагальну необхідність залучення додаткових інвестицій у розвиток ринків споживчих товарів і послуг [2], що у підсумку підвищить конкурентоспроможність вітчизняних виробників. Також надзвичайно інформативними є пропозиції К. Пугачевської щодо ринкового розвитку шляхом вирішення комплексу взаємоузгоджених завдань соціально-економічного та суспільно-політичного спрямування, зокрема створення кластерних структур сервісного характеру [8].

Разом 3 тим, попри доволі широке висвітлення науковцями означеної проблематики, дослідження у більшості $є$ фрагментарними і мають вузькоспеціалізований характер, що вимагає проведення системного аналізу розвитку споживчого ринку України.

Постановка завдання. Метою даної статті є системний аналіз стану i можливостей розвитку споживчого ринку України в сучасних умовах.

Виклад основного матеріалу дослідження. Споживчий ринок являє собою систему соціальноекономічних відносин, що грунтуються на механізмах конкуренції, ціноутворення та маркетингу, пов'язуючи сфери виробництва і споживання споживчих благ. Структура споживчого ринку включає три основних сегмента - роздрібні ринки продовольчих та непродовольчих товарів та ринок 
споживчих послуг (рис. 1), які зазвичай розглядають в якості самостійних, але тісно взаємодіючих ринкових одиниць, які в сукупності вирішують завдання задоволення потреб громадян у споживанні продовольчих і непродовольчих товарів та послуг.

Як бачимо, внутрішній споживчий ринок упродовж 2014-2020 pр. демонструє стабільне зростання, навіть попри зниження обсягу реалізації послуг населенню у 2020 р. через карантинні обмеження окремих видів діяльності, запроваджені Урядом внаслідок пандемії Covid-19. Зокрема, середній темп зростання обсягів реалізації продовольчих товарів складав $113,5 \%$, товарів непродовольчої групи - 111,2\%, послуг - 102,5\% (без урахування даних кризового 2020 р. - 109,1\%), що адекватно співвідноситься з середнім зростанням номінального ВВП $(118,1 \%)$ за цей же період (рис. 2). Загалом слід зазначити, що після падіння впродовж 2014-2015 pр. у 2016 р. внутрішній ринок України почав виходити 3 кризового стану, намітилися тенденції зростання ВВП, показників промислового виробництва та переробної галузі. Позитивна динаміка спостерігалась і у подальшому, зокрема у 2019 р. зростання реального ВВП становило 3,3\%, а у 2020 р. попри складні соціальноекономічні умови - 3,9\%, найвагомішу роль у чому відіграло приватне споживання, зумовлене покращенням споживчих настроїв.

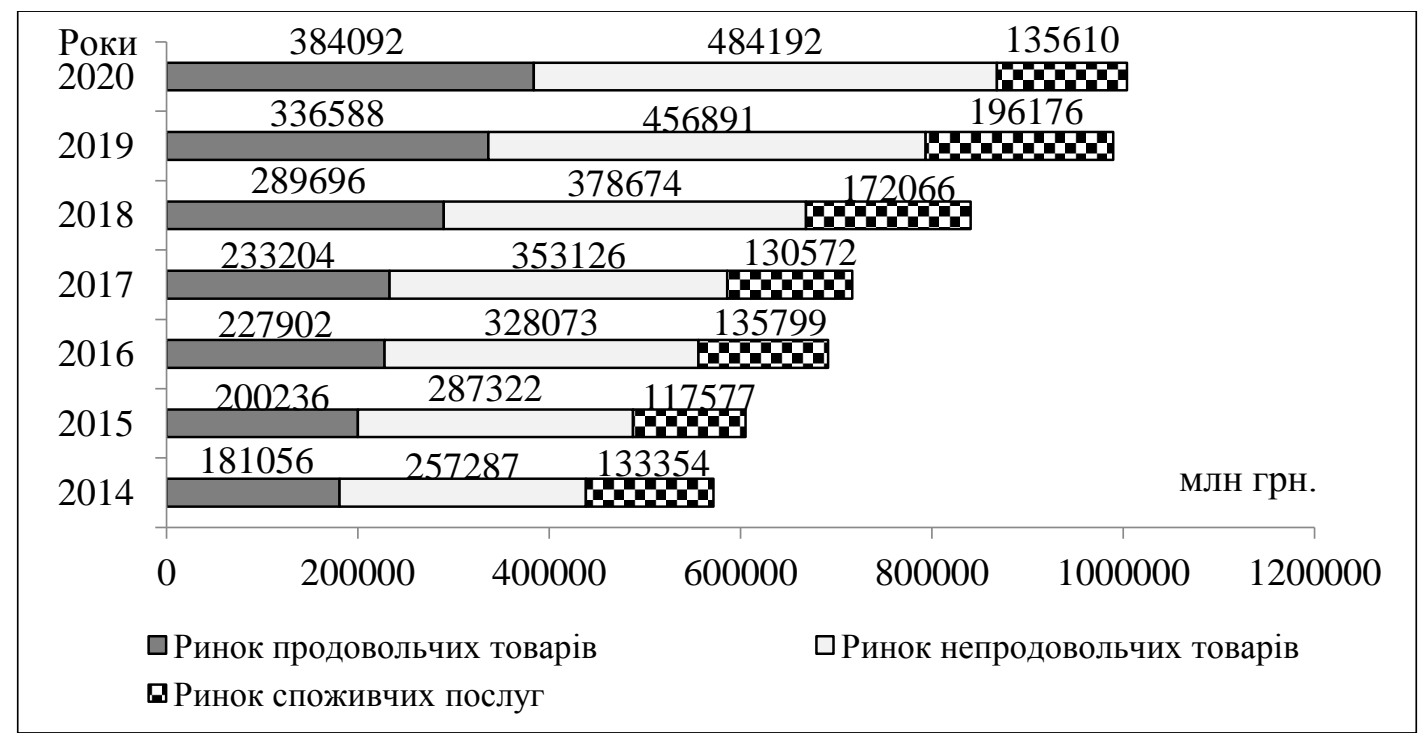

Рис. 1. Структурно-динамічний аналіз розвитку споживчого ринку України у 2014-2020 рр. Джерело: розраховано і побудовано за даними [3]

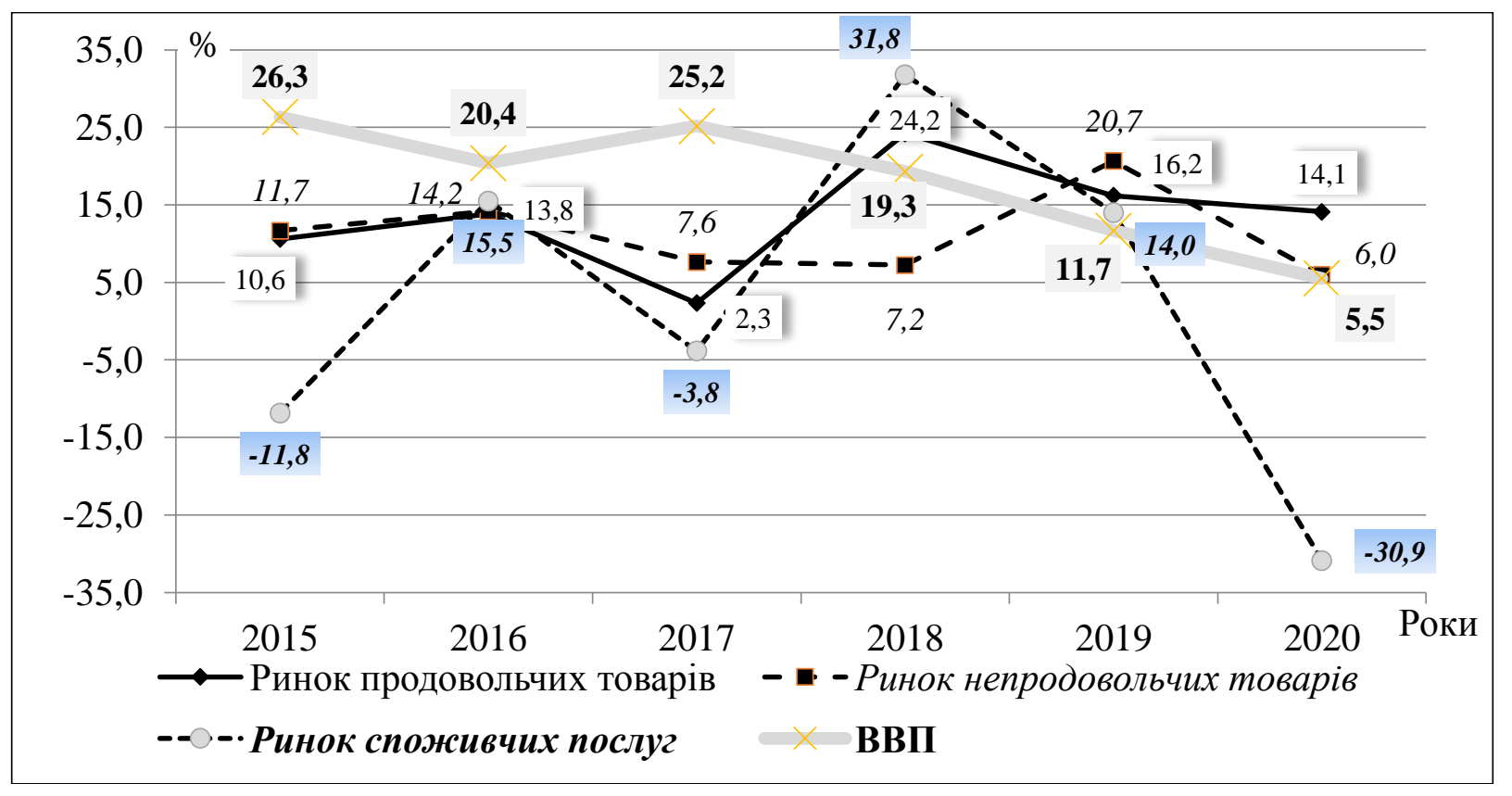

Рис. 2. Ланцюгові темпи змін номінального ВВП та обсягів реалізації товарів і послуг на споживчому ринку України у 2015-2020 рр. (в \% до попереднього року)

Джерело: розраховано і побудовано за даними $[3,6]$ 
За досліджуваний період значних змін зазнала товарна структура споживчих ринків продовольчих і непродовольчих товарів. Найбільші витрати домогосподарств традиційно припадали на продовольчу групу товарів (табл. 1), де, своєю чергою, спостерігалося значне зростання обсягів товарообороту молока і молочних продуктів (у понад 5 разів), хлібобулочних, кондитерських та макаронних виробів, плодово-овочевої продукції (близько 300\%).

Разом 3 тим, зазначимо, що стрімка динаміка товарообороту продовольчих товарів зумовлена не лише i не стільки пожвавленням споживацьких настроїв домогосподарств, але значною мірою була спричинена зростанням споживчих цін на товари. Зокрема, за окремими товарними позиціями за період 2016-2020 рр. зростання рівня цін сягнуло: молока і молочних продуктів - на 42,8\%, борошна, хлібобулочних та макаронних виробів - на 42,6$42,9 \%$, свинини - на 49,3\%, птиці (тушки курячої) на $32,9 \%$, олії соняшникової - на $27,6 \%$, яєць - на $24,8 \%$, риби мороженої - на $23,8 \%$, цукру - на $22,3 \%$. Отож, реальна динаміка продажів продукції на продовольчому внутрішньому ринку України значно відстає від зростання товарообороту (табл. 2).

Структурна динаміка обсягів реалізації на споживчому ринку продовольчих товарів України у 2014-2020 рр. (млн. грн.)

\begin{tabular}{|c|c|c|c|c|c|c|c|c|}
\hline $\begin{array}{c}\text { Товарні групи споживчого } \\
\text { ринку }\end{array}$ & 2014 & 2015 & 2016 & 2017 & 2018 & 2019 & 2020 & $\begin{array}{c}2020 / \\
2014, \%\end{array}$ \\
\hline Продовольчі товари, всього & 181056 & 200236 & 227902 & 233204 & 289696 & 336588 & 384092 & 212,1 \\
\hline М'ясо та м'ясопродукти & 20690 & 23844 & 25119 & 26417 & 33873 & 39362 & 44197 & 213,6 \\
\hline Риба і морепродукти & 7081 & 7434 & 8295 & 9583 & 12864 & 15431 & 18623 & 263,0 \\
\hline $\begin{array}{l}\text { Молоко та продукти } \\
\text { молочні }\end{array}$ & 8360 & 9899 & 12455 & 27017 & 33568 & 38311 & 44318 & 530,1 \\
\hline $\begin{array}{l}\text { Сир сичужний, плавлений } \\
\text { та кисломолочний }\end{array}$ & 5565 & 6630 & 7936 & 9456 & 12100 & 15068 & 17890 & 321,5 \\
\hline Масло вершкове & 2301 & 2494 & 3058 & 3234 & 3913 & 4875 & 5906 & 256,7 \\
\hline Харчові олії та жири & 2820 & 3733 & 3715 & 3480 & 4027 & 4435 & 5169 & 183,3 \\
\hline Яйця & 2417 & 3361 & 3606 & 3975 & 5391 & 5040 & 5856 & 242,3 \\
\hline Цукор & 2059 & 2481 & 2380 & 2785 & 2472 & 2714 & 2951 & 143,3 \\
\hline Вироби кондитерські & 14697 & 18538 & 22649 & 26884 & 34145 & 40916 & 43869 & 298,5 \\
\hline Борошно & 976 & 1281 & 1193 & 1118 & 1305 & 1687 & 1779 & 182,3 \\
\hline Вироби хлібобулочні & 4454 & 6278 & 7483 & 8454 & 10557 & 13603 & 14490 & 325,3 \\
\hline Крупи & 2461 & 3359 & 3645 & 4135 & 4650 & 5146 & 6007 & 244,1 \\
\hline Вироби макаронні & 1867 & 2382 & 2679 & 3019 & 3658 & 3835 & 5915 & 316,8 \\
\hline $\begin{array}{l}\text { Фрукти та овочі, свіжі та } \\
\text { перероблені }\end{array}$ & 13779 & 16460 & 19785 & 23329 & 29568 & 36611 & 42902 & 311,4 \\
\hline Напої алкогольні & 32087 & 38678 & 44551 & 46884 & 57651 & 65518 & 73483 & 229,0 \\
\hline Кава, чай, какао та прянощі & 5023 & 6793 & 7224 & 9035 & 10523 & 12034 & 13637 & 271,5 \\
\hline Сіль & 161 & 197 & 239 & 293 & 380 & 393 & 454 & 282,2 \\
\hline Напої безалкогольні & 7722 & 9737 & 11682 & 12902 & 16171 & 19146 & 20875 & 270,3 \\
\hline Вироби тютюнові & 29884 & 31065 & 32942 & 18107 & 19927 & 24806 & 30774 & 103,0 \\
\hline Інші продовольчі товари & 10793 & 12385 & 14490 & 12345 & 15826 & 14220 & 16151 & 149,6 \\
\hline
\end{tabular}

Джерело: побудовано за даними [3]

Таблиия 1

Таблиия 2

Динаміка середньомісячного споживання продуктів харчування в домогосподарствах України у 2014-2020 рp.

\begin{tabular}{|c|c|c|c|c|c|c|c|c|}
\hline Товарні групи споживчого ринку & 2014 & 2015 & 2016 & 2017 & 2018 & 2019 & 2020 & $\begin{array}{c}2020 / \\
2014, \%\end{array}$ \\
\hline М'ясо і м'ясопродукти & 4,2 & 4,4 & 4,5 & 4,8 & 4,9 & 5,7 & 5,1 & 122,6 \\
\hline Молоко і молочні продукти & 19,8 & 19,7 & 19,7 & 19,2 & 19 & 21 & 18,4 & 93,0 \\
\hline ЯйцЯ, шт. & 19,6 & 19,8 & 20 & 20 & 20 & 22 & 20 & 102,0 \\
\hline Риба і рибопродукти & 1,1 & 1,2 & 1,2 & 1,3 & 1,4 & 1,7 & 1,4 & 129,6 \\
\hline Цукор & 2,8 & 2,8 & 2,7 & 2,7 & 2,7 & 2,9 & 2,5 & 89,9 \\
\hline Олія та інші рослинні жири & 1,5 & 1,5 & 1,5 & 1,5 & 1,5 & 1,7 & 1,4 & 92,1 \\
\hline Картопля & 6,6 & 6,4 & 6,4 & 6 & 5,8 & 6,4 & 5,5 & 83,6 \\
\hline Овочі і баштанні & 9,7 & 9,2 & 9,8 & 6,7 & 6,7 & 7,6 & 6,5 & 66,7 \\
\hline Фрукти, ягоди, горіхи, виноград & 3,0 & 3,2 & 3,2 & 3,8 & 3,9 & 4,4 & 3,9 & 128,3 \\
\hline Хліб і хлібні продукти & 8,2 & 8,3 & 8,2 & 8,5 & 8,4 & 9,5 & 8,2 & 100,5 \\
\hline
\end{tabular}

Джерело: побудовано за даними [3] 
Аналогічна ситуація спостерігається і на ринку непродовольчих товарів (табл. 3), де впродовж 2014-2020 рр. товарооборот стабільно зростав майже за всіма товарними групами. Значну динаміку продемонстрував ринок оптики окулярної (у понад 5 разів), товарів для дітей (у 3,4 рази), меблів (у 3,2 рази) і товарів парфумерно-косметичної групи, що насамперед слід пов'язати з виходом з “тіні” товаровиробників і продавців даної продукції. Суттєво зросла реалізація комп'ютерів і програмного забезпечення (у 2,7 рази), садово-городнього устаткування та інвентарю (у 2,6 рази), побутових електротоварів (у 2,4 рази). Цікавою виявилася тенденція на ринку паливно-мастильних матеріалів, де на тлі суттєвого зростання товарообороту газу для автомобілів (у 2,2 рази) спостерігалася зворотна тенденція скорочення споживчого попиту на бензин моторний (на 41,5\%) та дизельне паливо (на $25,8 \%$ ). Окрім того, за цей період в Україні на чверть скоротився ринок книжкової та газетножурнальної продукції.

Структурна динаміка обсягів реалізації на споживчому ринку непродовольчих товарів України у

Таблиияя 3 2014-2020 рр. (млн грн.)

\begin{tabular}{|c|c|c|c|c|c|c|c|c|}
\hline $\begin{array}{c}\text { Товарні групи } \\
\text { споживчого ринку } \\
\end{array}$ & 2014 & 2015 & 2016 & 2017 & 2018 & 2019 & 2020 & $\begin{array}{c}2020 / \\
2014, \%\end{array}$ \\
\hline $\begin{array}{l}\text { Непродовольчі товари, } \\
\text { всього }\end{array}$ & 257287 & 287322 & 328073 & 353126 & 378674 & 456891 & 484192 & 188,2 \\
\hline $\begin{array}{l}\text { Товари текстильні та } \\
\text { галантерея }\end{array}$ & 1716 & 1529 & 1747 & 1835,4 & 2391,7 & 2667,6 & 2916 & 169,9 \\
\hline Одяг & 10730 & 12752 & 15202 & 17580 & 21075 & 25589 & 25112 & 234,0 \\
\hline Взуття & 4854 & 5486 & 5590 & 5784 & 6155 & 8001 & 8171 & 168,3 \\
\hline $\begin{array}{l}\text { Товари парфумерно- } \\
\text { косметичні }\end{array}$ & 10903 & 14273 & 17863 & 20638 & 23678 & 30378 & 31029 & 284,6 \\
\hline $\begin{array}{l}\text { Годинники та ювелірні } \\
\text { вироби }\end{array}$ & 627 & 365 & 385 & 281 & 841 & 1946 & 1788 & 285,2 \\
\hline Книги, газети, журнали & 2418 & 2416 & 2592 & 1472 & 1712 & 1755 & 1817 & 75,1 \\
\hline Канцелярські товари & 981 & 1309 & 1432 & 1406 & 1706 & 1750 & 2142 & 218,3 \\
\hline $\begin{array}{l}\text { Комп’ютери, програмне } \\
\text { забезпечення }\end{array}$ & 3648 & 3413 & 4294 & 4512 & 4791 & 7531 & 9904 & 271,5 \\
\hline $\begin{array}{l}\text { Телекомунікаційне } \\
\text { устатковання }\end{array}$ & 9298 & 8757 & 11716 & 14517 & 13319 & 15589 & 16083 & 173,0 \\
\hline Ігри та іграшки & 1402 & 1878 & 2309 & 2901 & 3616 & 4557 & 4725 & 337,0 \\
\hline $\begin{array}{l}\text { Мотоцикли, деталі та } \\
\text { приладдя для них }\end{array}$ & 169 & 255 & 206 & 230 & 239 & 416 & 556 & 328,9 \\
\hline Автомобілі та автотовари & 29565 & 30080 & 44503 & 47486 & 48408 & 60807 & 65006 & 219,9 \\
\hline $\begin{array}{l}\text { Спортивний, } \\
\text { туристичний інвентар }\end{array}$ & 1143 & 1240 & 1375 & 1530 & 2164 & 2627 & 3425 & 299,7 \\
\hline Меблі & 2057 & 2158 & 2542 & 3354 & 4266 & 5791 & 6652 & 323,4 \\
\hline $\begin{array}{l}\text { Килими, покриття для } \\
\text { підлоги та стін }\end{array}$ & 2912 & 3416 & 4078 & 5083 & 5848 & 6260 & 6632 & 227,7 \\
\hline Побутові електротовари & 11835 & 12710 & 14013 & 19443 & 21343 & 25387 & 28371 & 239,7 \\
\hline Матеріали будівельні & 15880 & 17964 & 18761 & 24674 & 29389 & 31949 & 33868 & 213,3 \\
\hline $\begin{array}{l}\text { Добрива й агрохімічна } \\
\text { продукція }\end{array}$ & 353 & 343 & 317 & 247 & 333 & 488 & 558 & 157,9 \\
\hline $\begin{array}{l}\text { Садово-городнє } \\
\text { устаткування }\end{array}$ & 2236 & 2406 & 2863 & 3356 & 4113 & 4739 & 5833 & 260,9 \\
\hline $\begin{array}{l}\text { Фармацевтичні, медичні } \\
\text { та ортопедичні товари }\end{array}$ & 35864 & 46271 & 55981 & 63924 & 75979 & 92076 & 100404 & 280,0 \\
\hline Оптика окулярна & 323 & 416 & 624 & 882 & 1278 & 1720 & 1670 & 517,0 \\
\hline Бензин моторний & 47935 & 48243 & 46086 & 36672 & 27621 & 29833 & 28064 & 58,5 \\
\hline $\begin{array}{l}\text { Дизельне пальне } \\
\text { (газойль) }\end{array}$ & 29992 & 31315 & 26716 & 25080 & 20332 & 24110 & 22254 & 74,2 \\
\hline $\begin{array}{l}\text { Газ стиснений та скрап- } \\
\text { лений для автомобілів }\end{array}$ & 7639 & 10509 & 12161 & 13734 & 12587 & 15445 & 16662 & 218,1 \\
\hline Матеріали мастильні & 333 & 423 & 442 & 302 & 279 & 375 & 599 & 179,9 \\
\hline $\begin{array}{l}\text { Інші непродовольчі } \\
\text { товари }\end{array}$ & 12374 & 15539 & 20090 & 28506 & 34257 & 41104 & 43845 & 354,3 \\
\hline
\end{tabular}

Джерело: побудовано за даними [3] 
У 2020 р. стрімке поширення пандемії Covid-19 та обмеження, введені Урядом для іiі подолання, визначили початок кризової ситуації на споживчому ринку України. Внаслідок карантинних обмежень погіршилися показники діяльності всіх секторів економіки, а вторинні ефекти від карантинних обмежень та низький споживчий попит на тлі погіршення споживчих настроїв поглибили спад у виробництві споживчих товарів, у тому числі харчових. Зазначимо, що у 2020 р. середньомісячні сукупні витрати українських домогосподарств на внутрішньому споживчому ринку скоротилися 3 9629,2 грн. до 9413,0 грн. (на 2,2\%), при цьому частка витрат на продовольчі товари зросла $349,4 \%$ до $51,4 \%$, тоді як на непродовольчі товари і послуги знизилася відповідно з 26,4\% до $24,7 \%$ та $315,6 \%$ до $14,0 \%$. До певної міри це було обумовлено інституційним обмеженням певних видів діяльності на внутрішніх ринках непродовольчих товарів i послуг. Зокрема, слід відзначити скорочення частки витрат на транспортні послуги 3 4,2\% до 3,8\% та готельно-ресторанне обслуговування 3 2,2\% до 1,2\%. Разом 3 тим, частка неспоживчих витрат (допомога іншим особам, купівля акцій, сертифікатів, вклади до банків, будівництво та капітальний ремонт житла тощо) зросла у 2020 р. $з$ 8,6\% до 9,4\%. При цьому загальне зниження споживчих сукупних витрат домогосподарств 3 91,4\% до 90,1\% можна розглядати в якості маркера невпевненості громадян у стабільному соціально-економічному розвитку в країні.

Перманентний спад економіки, знецінення гривні і скорочення поточних видатків бюджету призвели у 2015 р. до зменшення рівня доходів населення і підвищення рівня бідності з 3,3\% до 5,8\%, помірна бідність зросла відповідно з 15,2\% до $22,2 \%$ за рахунок зниження реальної заробітної плати на 20\% і зростання рівня безробіття до 9,5\%. Найгостріше ці проблеми проявлялися в зоні військового конфлікту на сході України та серед внутрішньо переміщених осіб. До зростання рівня бідності спричинило і підвищення тарифів на житлово-комунальні послуги, попри оновлення державної програми субсидій (у 2017 р. нею було охоплено понад 7 млн. українських домогосподарств). На подолання проблеми високого рівня бідності були спрямовані реалізація державної Стратегії подолання бідності та приєднання України до програми ООН “Цілі Сталого Розвитку 2016-2030” [5], цільовими орієнтирами яких є ліквідація абсолютної бідності (5,05 дол. США доходу на добу), зниження до 25\% відносної бідності, скорочення в 10 разів частки осіб, рівень споживання яких є меншим за рівень фактичного прожиткового мінімуму. Попри це, рівень бідності в Україні у 2019 р. становив 3,5\%, бідності працюючих осіб - близько 20\%, відносної бідності - близько 25\%, бідності серед дітей - 32,6\%. Споживання нижче прожиткового мінімуму зафіксовано у 2019 р. на рівні 22,1\%, у 2020 р. - на рівні $28,3 \%$.

Споживчі потреби домогосподарства задовольняли за рахунок ресурсів, які надходили 3 різних джерел. Середньомісячні сукупні ресурси домогосподарств у 2020 р. становили 12118 грн., що на 22\% більше, ніж у 2018 р. При цьому в розрахунку на 1 особу середньомісячні ресурси складали 5743 грн. Домінуючу частку структури ресурсів становили грошові доходи $(92 \%)$. Частка доходів від зайнятості складала $64 \%$ ресурсів домогосподарств, у т.ч. на оплату праці припадало $57 \%$, на доходи від підприємницької діяльності та самозайнятості - 7\%. Частка соціальних допомог (включаючи пенсії, стипендії та готівкові субсидії на оплату житлово-комунальних послуг) становила 20\% ресурсів домогосподарств. Ефективність перерозподільного потенціалу соціальної інфраструктури демонструє розподіл доходів домогосподарств, сформованих із бюджетних соціальних трансфертів (рис. 3).

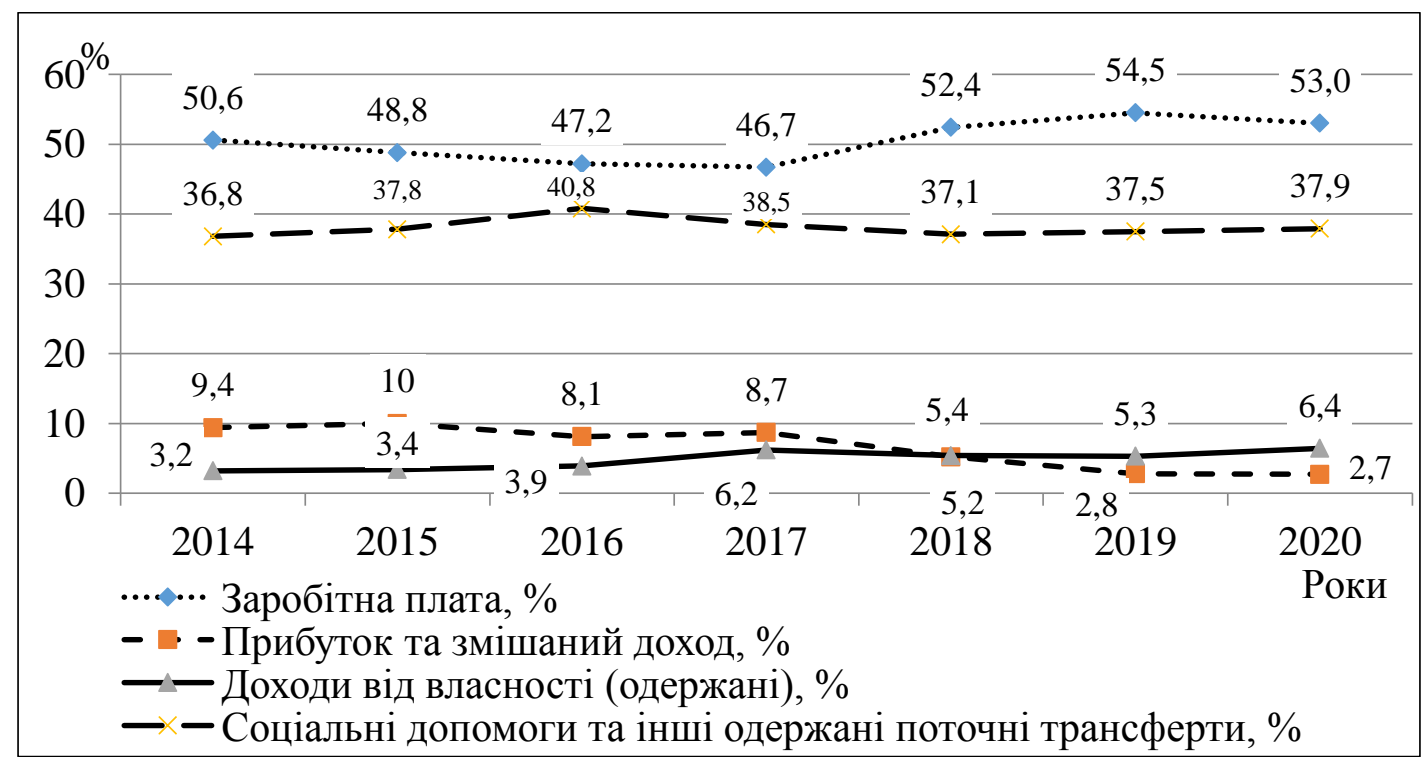

Рис. 3. Структурна динаміка доходів населення України у 2014-2019 рр.

Джерело: розраховано і побудовано за даними [3] 


\section{Herald of Lviv University of Trade and Economics. Economic Sciences. № 64, 2021}

Структурна динаміка обсягів реалізації на споживчому ринку послуг України у 2014-2020 рр. (млн грн)

\begin{tabular}{|c|c|c|c|c|c|c|c|c|}
\hline $\begin{array}{c}\text { Категорія споживчих } \\
\text { послуг }\end{array}$ & 2014 & 2015 & 2016 & 2017 & 2018 & 2019 & 2020 & $\begin{array}{l}2020 / \\
2014, \%\end{array}$ \\
\hline Усього & 163403 & 166961 & 170520 & 174079 & 172066 & 196176 & 175348 & 107,3 \\
\hline $\begin{array}{l}\text { Транспорт, складське } \\
\text { господарство, поштова та } \\
\text { кур'єрська діяльність }\end{array}$ & 64286 & 68796 & 64033 & 59087 & 50578 & 51653 & 26454 & 41,2 \\
\hline $\begin{array}{l}\text { Тимчасове розміщування } \\
\text { й організація харчування }\end{array}$ & 33521 & 30543 & 27566 & 24589 & 19925 & 23765 & 12212 & 36,4 \\
\hline $\begin{array}{l}\text { Інформація та } \\
\text { телекомунікації }\end{array}$ & 21200 & 29950 & 32300 & 38650 & 44378 & 52885 & 56789 & 267,9 \\
\hline $\begin{array}{l}\text { Операції з нерухомим } \\
\text { майном }\end{array}$ & 4933 & 2835 & 2237 & 2639 & 3233 & 3005 & 4090 & 82,9 \\
\hline $\begin{array}{l}\text { Професійна, наукова та } \\
\text { технічна діяльність }\end{array}$ & 5913 & 2783 & 3254 & 3724 & 3236 & 3724 & 4036 & 68,3 \\
\hline $\begin{array}{l}\text { Діяльність у сфері } \\
\text { адміністративного та } \\
\text { допоміжного обслуго- } \\
\text { вування }\end{array}$ & 6874 & 7998 & 9922 & 11846 & 13276 & 16888 & 16918 & 246,1 \\
\hline Освіта & 11746 & 10219 & 14692 & 16166 & 17691 & 19417 & 20228 & 172,2 \\
\hline $\begin{array}{l}\text { Охорона здоров'я та } \\
\text { надання соціальної допо- } \\
\text { моги }\end{array}$ & 10301 & 9585 & 12140 & 13379 & 15467 & 19753 & 31249 & 303,4 \\
\hline $\begin{array}{l}\text { Мистецтво, спорт, розва- } \\
\text { ги та відпочинок }\end{array}$ & 3612 & 3425 & 3538 & 3151 & 3427 & 4184 & 2520 & 69,8 \\
\hline Інші види послуг & 1017 & 827 & 838 & 848 & 854 & 900 & 853 & 83,9 \\
\hline
\end{tabular}

Джерело: побудовано за даними [3]

Аналізуючи розвиток ринку споживчих послуг в Україні у 2014-2020 рр., підкреслимо тенденції перерозподілу структури споживчого попиту населення, скорочення обсягів соціальних і науково-технічних послуг, зростання частки витрат домогосподарств на житлово-комунальне обслуговування, збільшення обсягів ринкових послуг в освітній та медичній галузях (табл. 4), а також поглиблення розриву між ринковими пропозиціями та платоспроможним попитом.

У структурі загального обсягу реалізованих на ринку послуг найбільша частка припадає на категорію "Транспорт, складське господарство, поштова та кур'єрська діяльність" (середнє значення за період 2014-2020 pр. становить 31,6\%), хоча спостерігається помітна тенденція до зменшення витрат домогосподарств на цей вид послуг. Суттєве скорочення (на 63,6\%) спостерігалось і на ринку тимчасового розміщування та організації харчування, який займає $14,1 \%$ у загальній структурі ринку послуг. Найсуттєвіше падіння обсягів реалізації послуг було зафіксовано у 2020 р., що пов'язано 3 тимчасовою забороною та подальшими обмеженнями діяльності закладів ресторанного господарства, торговельно-розважальних центрів, фітнесцентрів, закладів торговельного і побутового обслуговування населення. Локдаун негативно позначився і на інфраструктурному супроводі розвитку споживчого ринку, оскільки під повну або часткову заборону потрапили перевезення пасажирів.

Водночас у 2014-2020 pр. певні сегменти ринку споживчих послуг демонстрували стабільне зростання. Насамперед йдеться про ринок інформаційних та телекомунікаційних послуг (частка у загальній структурі становить 22,7\%), який зріс за цей період у понад 2,7 рази. Про все більше усвідомлення споживачами важливості знань, умінь та навичок у сучасному соціально-економічному середовищі свідчить зростання на $72,2 \%$ ринку платних освітніх послуг, хоча їх частка у загальній структурі послуг складає всього 9\%. Найбільші темпи зростання (понад 3 рази) демонструє ринок послуг в галузі охорони здоров'я та соціальних послуг, частка якого у структурі ринку споживчих послуг становить в середньому 9,2\%. Тут варто зазначити, що основний прорив у реалізації даного виду послуг відбувся саме у 2020 р. (зростання на $58,2 \%$ за рік).

Для отримання більш об'єктивної характеристики впливу розвитку внутрішнього ринку споживчих послуг на загальні параметри економічної системи України ми проаналізували факторний вплив обсягів реалізації на споживчих ринках продовольчих $\left(x_{1}\right)$ і непродовольчих $\left(x_{2}\right)$ товарів та послуг $\left(x_{3}\right)$ на динаміку ВВП (y) у 2014-2020 pp. (рис. 4). 


\begin{tabular}{|c|c|c|c|c|}
\hline & $y$ & $x_{1}$ & $x_{2}$ & $x_{3}$ \\
\hline$y$ & 1 & 0,9591 & 0,976 & 0,6217 \\
\hline$x_{1}$ & 0,9591 & 1 & 0,9842 & 0,5441 \\
\hline$x_{2}$ & 0,976 & 0,9842 & 1 & 0,5646 \\
\hline$x_{3}$ & 0,6217 & 0,5441 & 0,5646 & 1 \\
\hline
\end{tabular}

Рис. 4. Матриця парних коефіцієнтів кореляції

Джерело: власні розрахунки автора

Попри досить вагомий агрегований вплив зовнішніх чинників, отримане рівняння регресії $y=-0,1 x_{1}+11,2 x_{2}+3,8 x_{3}-1647370,6\left(R^{2}=0,96\right)$ свідчить, що стан споживчого ринку продовольчих товарів практично не впливає на динаміку номінального ВВП, тоді як зростання ринків непродовольчих товарів та послуг гарантовано призводить до збільшення ВВП. Такий результат дає підстави значно розширити визнання ролі внутрішнього споживчого ринку i перейти від концепту локального явища до концепту цілісної системи соціально-економічних відносин, що включають як взаємозв'язки та взаємодію між виробниками і споживачами, так і взаємозв'язки в локаціях “інституції - споживачі” та “інституції - продавці”. Відповідно, це дозволяє формалізувати роль інституційного регулювання щодо окреслення правил і обмежень, удосконалення фіскальної політики, активізації інвестиційних процесів, розбудови ринкової інфраструктури для стабільного розвитку та ефективного функціонування споживчого ринку як елемента загальнодержавної соціально-економічної системи. Разом 3 тим, постає ще один надзвичайно важливий аспект цілепокладання інституційного регулювання розвитку внутрішнього споживчого ринку, а саме: задоволення потреб споживачів, які виступають кінцевою ланкою ринкових відносин.

Висновки i перспективи подальших досліджень у даному напрямі. Проведене дослідження засвідчило, що внутрішній споживчий ринок товарів упродовж 2014-2020 рр. стабільно зростав, при цьому його товарна структура змінювалася. Найбільші витрати домогосподарств припадали на продовольчу групу товарів, де спостерігалося стрімке зростання споживчих цін. Водночас середньомісячні сукупні витрати домогосподарств на споживчому ринку скоротилися, частка витрат на непродовольчі товари i послуги знизилася, що свідчить про соціальноекономічну невпевненість споживачів. На ринку споживчих послуг спостерігався суттєвий перерозподіл структури попиту у бік зростання частки житловокомунального обслуговування та послуг в освітній i медичній галузях. Факторний аналіз засвідчив суттєвий вплив розвитку ринків непродовольчих товарів та послуг на зростання ВВП України. Системний аналіз реального стану і перспективних можливостей розвитку споживчого ринку має стати підгрунтям для розробки адекватного інституційного інструментарію його концептуальних перетворень.

\section{ЛІТЕРАТУРА}

1. Громов В. Б. Механізм формування споживчого попиту в економіці України / Громов В. Б. // Формування ринкових відносин в Україні. 2018. - № 7-8. - С. 57-67.

2. Данилюк Т. Сучасний стан та перспективи розвитку ринку послуг України / Данилюк Т. // Економічний часопис Східноєвропейського національного університету імені Лесі Українки. 2015. - № 3. - С. 19-23.

3. Державна служба статистики України [Електронний ресурс]. - Режим доступу: http://www.ukrstat.gov.ua/.

4. Колеснікова К. С. Перспективи розвитку інфраструктури ринку споживчих товарів / Колеснікова К. С., Руденко Т. С. // Розвиток торгівлі та підприємництва в Україні: тенденції та перспективи : збірник наукових праць за матеріалами міжнародної науково-практичної конференції (Одеса, 25-26 травня 2017 р.). - Одеса : OTEI KHTEУ, 2017. - 124 c. C. 47-49.

5. Міністерство економічного розвитку i торгівлі України. Цілі сталого розвитку: Україна. Національна доповідь. [Електронний ресурс]. Режим доступу: http://un.org.ua/images/ SDGs_NationalReportUA_Web_1.pdf.

6. Міністерство фінансів України. Валовий внутрішній продукт (ВВП) в Україні 2020. [Електронний ресурс]. - Режим доступу: https://index.minfin.com.ua/ua/economy/gdp/.

7. Попадинець Н. М. Регіональний ринок споживчих товарів: сутність і засадничі положення функціонування / Попадинець Н. М. // Регіональна економіка. - 2017. - № 1. - С. 17-22.

8. Пугачевська К. Й. Сфера послуг в Україні: особливості розвитку та стратегічні перспективи / Пугачевська К. Й. // Науковий вісник Міжнародного гуманітарного університету. - 2016. - № 18. C. 52-55.

9. Уманців Ю. М. Розвиток внутрішнього ринку споживчих товарів України / Уманців Ю. М., Катран М. В. // Бізнес Інформ. - 2017. - № 8 (475). - C. 271-275.

10. Федоронько Н. І. Особливості сучасного становища ринку послуг України / Федоронько Н. I., Ковальчук Н. О. // Молодий вчений. - 2017. - № 3 (43). - C. 871-874. 
11. Чорна М. В. Особливості формування нового ринкового простору на вітчизняному споживчому ринку / Чорна М. В., Бугріменко Р. М., Остін 3. // Бізнес Інформ. - 2019. - № 1 (492). C. 241-248.

12. Шликова В. О. Розвиток споживчого ринку України в умовах макроекономічної нестабільності / Шликова В. О., Леванда О. М. // Бізнес Інформ. 2019. - № 11. - С. 247-258.

13. Яхно Т. П. Соціалізація економіки та індивідуалізація споживчого ринку як необхідні передумови національного розвитку / Яхно Т. П. // Вісник Сумського національного аграрного університету. Серія : Економіка і менеджмент. 2019. - Вип. 2. - С. 12-17.

\section{REFERENCES}

1. Hromov, V. B. (2018), Mekhanizm formuvannia spozhyvchoho popytu $\mathrm{v}$ ekonomitsi Ukrainy, Formuvannia rynkovykh vidnosyn v Ukraini, № 7-8, s. 57-67.

2. Danyliuk T. (2015), Suchasnyj stan ta perspektyvy rozvytku rynku posluh Ukrainy, Ekonomichnyj chasopys Skhidnoievropejs'koho natsional'noho universytetu imeni Lesi Ukrainky, № 3, s. 19-23.

3. Derzhavna sluzhba statystyky Ukrainy, available at: http://www.ukrstat.gov.ua/.

4. Kolesnikova, K. S. and Rudenko, T. S. (2017), Perspektyvy rozvytku infrastruktury rynku spozhyvchykh tovariv, Rozvytok torhivli ta pidpryiemnytstva v Ukraini: tendentsii ta perspektyvy : zbirnyk naukovykh prats' za materialamy mizhnarodnoi naukovo-praktychnoi konferentsii (Odesa, 25-26 travnia 2017 r.), OTEI KNTEU, Odesa, 124 s. S. 4749.

5. Ministerstvo ekonomichnoho rozvytku i torhivli Ukrainy. Tsili staloho rozvytku: Ukraina. Natsion- al'na dopovid', available at: http://un.org.ua/images/ SDGs_NationalReportUA_Web_1.pdf.

6. Ministerstvo finansiv Ukrainy. Valovyj vnutrishnij produkt (VVP) v Ukraini 2020, available at: https://index.minfin.com.ua/ua/economy/gdp/.

7. Popadynets', N. M. (2017), Rehional'nyj rynok spozhyvchykh tovariv: sutnist' i zasadnychi polozhennia funktsionuvannia, Rehional'na ekonomika, № 1, s. 17-22.

8. Puhachevs'ka, K. J. (2016), Sfera posluh v Ukraini: osoblyvosti rozvytku ta stratehichni perspektyvy, Naukovyj visnyk Mizhnarodnoho humanitarnoho universytetu, № 18, s. 52-55.

9. Umantsiv, Yu. M. and Katran, M. V. (2017), Rozvytok vnutrishn'oho rynku spozhyvchykh tovariv Ukrainy, Biznes Inform, № 8 (475), s. 271-275.

10. Fedoron'ko, N. I. and Koval'chuk, N. O. (2017), Osoblyvosti suchasnoho stanovyscha rynku posluh Ukrainy, Molodyj vchenyj, № 3 (43), s. 871 874.

11. Chorna, M. V. Buhrimenko, R. M. and Ostin Z. (2019), Osoblyvosti formuvannia novoho rynkovoho prostoru na vitchyznianomu spozhyvchomu rynku, Biznes Inform, № 1 (492), s. 241-248.

12. Shlykova, V. O. and Levanda, O. M. (2019), Rozvytok spozhyvchoho rynku Ukrainy $\mathrm{v}$ umovakh makroekonomichnoi nestabil'nosti, Biznes Inform, № 11, s. 247-258.

13. Yakhno, T. P. (2019), Sotsializatsiia ekonomiky ta indyvidualizatsiia spozhyvchoho rynku iak neobkhidni peredumovy natsional'noho rozvytku, Visnyk Sums'koho natsional'noho ahrarnoho universytetu. Seriia : Ekonomika i menedzhment., vyp. 2, s. 12-17.

Стаття надійшла до редакиії 8 серпня 2021 року 